\title{
Entrevista com Ana Rieper: documentários musicais como um território de afetos
}

\author{
Guilherme Sarmiento \& Lucas Ravazzano*
}

Em 2015, uma pequena equipe de gravação subia as ladeiras de Santa Tereza para entrevistar a cineasta carioca Ana Rieper. O material audiovisual faria parte de um conjunto de ações previstas pelo projeto de pesquisa Cinema Musical na América Latina, coordenado pelo Professor Guilherme Maia, e hoje pode ser encontrado no site do Laboratório da Análises Fílmicas da Universidade Federal da Bahia (UFBA) numa edição videográfica resumida. ${ }^{1}$ Do alto, a Baía de Guanabara mostrava-se um pouco mais cada vez que o pequeno bonde subia a estreita faixa de trilho, cercada de sobrados. Fomos levados até ali para escutarmos o relato de realização do premiado longa-metragem Vou rifar meu coração, documentário musical finalizado em 2011 e lançado no cinema no ano seguinte. O modo afetuoso com que a diretora abordou a música "brega", seu imaginário, seus personagens, ajudou, como ela mesma admite na entrevista, a colocar os holofotes sobre a cultura popular urbana e, por conta dessa sutil mudança de foco, referendar movimentos ou expressões relegados até então à marginalidade.

Acompanhado de outras muitas produções que atualmente alimentam o circuito de festivais e, algumas vezes, são lançadas nos cinemas, Vou rifar meu coração utiliza o gênero documentário para abordar de forma lúdica e emotiva o universo musical brasileiro. De uns anos para cá, os cineastas vêm de maneira contínua aproveitando-se deste tema não somente para atrair o grande público, mas também para entender a relação carnal, identitária, que se estabelece entre a cultura e suas fontes melódicas, rítmicas e literárias. Não há como negar a importância adquirida pela canção no século XX, manancial de crônicas, de gírias, de vozes, que juntas compõem um conjunto de atitudes e

* Guilherme Sarmiento: Universidade Federal do Recôncavo da Bahia - UFRB, Grupo de Pesquisa Cinema Musical na América Latina, LAF-Laboratório de Análises Fílmicas da UFBA. 40170-115, Salvador- BA, Brasil. E-mail: guilhermesarmiento@outlook.com

Lucas Ravazzano: Doutorando. Universidade Federal da Bahia - UFBA, Grupo de Pesquisa Cinema Musical na América Latina, LAF-Laboratório de Análises Fílmicas da UFRB. 40170-115, Salvador-BA, Brasil. E-mail: ravazzano@globo.com

Registro da entrevista: André Félix. Apoio técnico: Arthur Dias. Transcrição da entrevista: Lucas Ravazzano.

1. Disponível em: http://lafposcom.com.br/laf-entrevista-ana-rieper/ 
elocuções capazes de definir a "alma" brasileira. Isso ajudou a impulsionar uma série de obras denominadas de biografias musicais desde a retomada da produção audiovisual, como Dois filhos de Francisco (2005), Tim Maia (2014), Elis (2016), e, com igual força e vigor documentários que se embrenharam em arquivos audiovisuais para de lá retirarem o registro da passagem de ícones do cancioneiro nacional, como Simonal, Tom Jobim, Vinícius de Moraes, dentre outros nomes importantes para a concepção deste território imaginário, onde só se chega quando o ouvido se permite uma nostálgica escuta.

E é a partir dessa chave onde as linhas melódicas circunscrevem os limites de um determinado espaço que a leitura de Vou rifar meu coração ganha coerência temática ao lado dos curtas iniciais da diretora. Formada em Geografia pela Universidade Federal Fluminense, Ana Rieper observa o universo musical como parte das ancoragens que permitem ao Ser Humano criar sua identidade social. Escutar uma música, uma canção, não é um ato desinteressado porque nele se agita sempre as lembranças de fundação de um território. Neste sentido, a materialidade que configura aspectos de uma composição, seus elementos imanentes, são colocados em primeiro plano para que os desenhos dessa topografia fiquem bastante visíveis no horizonte da espectatorialidade. Os referenciais geográficos, nesta visão criativa, conformam o caráter humano a um catálogo de "tipologias" que, em seu movimento de reciprocidade, devolvem ao mundo suas funções elementares. Em seu primeiro curta, Saara (1998), por exemplo, Ana Rieper utiliza a rádio comunitária para fixar os passantes em um ambiente onde a compra de miudezas vem embalada por "ritz" musicais, um ambiente periférico, porém integrado ao consumo de bens produzidos pela indústria cultural. Em Mataram meu gato (2006), o samba enredo homônimo inaugural da Gato de Bom Sucesso serve para resgatar a história de fundação da favela Nova Holanda, do Complexo da Maré, originada pelo trauma de uma remoção. Portanto, quando nos voltamos para a realização de seu primeiro longa-metragem percebemos que ele se encaixa dentro de um programa onde a sonoridade cumpre um papel fundamental para assentar as personas documentais em seu lugar, ou melhor, em sua paisagem, já que as referências geológicas por si mesmas não conseguem retratar as práticas saturadas de subjetividade.

Nesta entrevista, Ana Rieper revela tudo isso com riqueza de detalhes. Temos aqui a oportunidade de acompanhar bem de perto todo o processo de pesquisa e realização do documentário Vou rifar meu coração, e, em igual medida, entender a construção de um olhar atravessado por formações distintas. $\mathrm{Ou}$ melhor, entender os caminhos que permitem com que a geografia como "conhecimento" se integre a suas funções narrativas, estéticas e estilísticas. 
Lugar e data da entrevista: Rio de Janeiro, 29 de agosto de 2015.

Guilherme Sarmiento: Eu queria que você falasse um pouco de sua experiência com o documentário musical, seu processo de pesquisa para o filme Vou rifar meu coração...

Ana Rieper: Eu venho da Geografia e então foi uma coisa natural para mim fazer filmes sobre lugares. Sempre gostei muito de música, sou daquelas pessoas que leem ficha técnica de disco, sabe? Gosto de entender, de saber quem tocou, de saber quem fez a capa do disco e de conhecer a obra. Eu gosto muito de ouvir música... Então, mesmo não tendo inicialmente esse impulso de fazer necessariamente musicais, meus filmes sempre tiveram muita música, desde o primeiro que eu fiz, em 1997(Saara).

A música sempre foi narradora, mais especificamente, a canção, no sentido de divulgar as notícias sobre o mundo. Eu faço filme pra noticiar o mundo, pra olhar pro mundo e contar para alguém alguma coisa que vi. Então, eu acho que as canções ajudam a contar histórias, falar a respeito de coisas num registro que é muito pessoal, muito íntimo. Uma vez li um texto para a pesquisa do filme Vou rifar meu coração, que afirmava que a música ia muito além da frieza do som, porque cada um se sente tocado de uma maneira diferente. Ela tem a ver com a nossa história, com o contexto em que a gente ouve; tem a ver com a nossa vida naquele momento, nossa vida antes daquele momento, memórias afetivas e sentimentos que se despertam na gente. Ajuda a falar sobre o mundo de uma perspectiva não expositiva, que é o que eu busco quando faço filmes. Tentar chegar em um tipo de informação que sensibiliza, que comunica e que faz isso em um sentido interpessoal, por assim dizer, subjetivo.

No caso do processo de pesquisa do Vou rifar meu coração, mergulhei de cabeça nesse universo de músicas conhecidas como "brega". Pesquisando desde os anos 1960 até a música mais contemporânea, passando por vários artistas, descobri um mundo vastíssimo. O ponto de partida foram algumas canções que me cativaram. A partir disso, comecei uma varredura, eu queria conhecer mais desse mundo, entender suas canções, quais eram as mais importantes, quais delas possuíam uma história interessante para colocar no filme. Um percurso muito próximo daquele de uma pesquisa etnográfica. Ao pesquisar personagens e locações, em um processo longo, andando pelo interior de Sergipe, Alagoas e Recife, anotei todas as músicas que eu ouvia, querendo entender suas relações com a paisagem, como mobilizavam aquelas pessoas. Foi muito interessante porque absolutamente não eram todas contemporâneas, o pessoal ouve muito Waldick Soriano, Diana, Agnaldo Timóteo... 
G.S.: Você falou um pouco sobre seu primeiro curta, Saara, local bastante tradicional do Centro do Rio de Janeiro, e ele já traz um pouco dessa sua fascinação pelo universo popular e, também, localiza o espectador nessa geografia afetiva, digamos assim, que me parece bastante presente em seu trabalho. A música ajuda a muito nessa localização não?

A.R.: No caso do Vou rifar meu coração, que é propriamente um filme musical porque trata de um determinado estilo de música, que tem depoimentos de cantores e compositores falando sobre seu processo de criação, ela é o fio condutor. Isso é muito evidente, essa relação da música como espelho da vida, como algo que constitui a sua história em determinado lugar. No caso do documentário sobre o Saara, essa relação também é expressiva: o Saara é uma área de comércio antiga aqui no Rio de Janeiro, constituída por imigrantes. Imigrantes judeus e imigrantes árabes e, nos últimos anos, recebeu também os orientais, chineses, coreanos e tal. É um lugar de encontro de culturas, e como todos esses grupos se tornaram brasileiros e cariocas, cada um traz uma informação diferente. É um filme que fala da história do mundo, das guerras que levaram aquelas pessoas a se encontrarem ali, com seus hábitos. Queria com esse filme entender a história como algo em conexão com o presente, para que as falas do filme não fossem meros relatos sem relação com a vida.

As pessoas falam do presente, sobre suas vidas imediatas e então tentei elaborar uma paisagem sonora a partir daquele lugar. Algumas músicas eu usei no filme por tocarem na rádio comunitária do Saara. Utilizei uma canção de um disco tropicalista da Gal Costa, composta pelo Jorge Ben, que se chama Tuaregue. Fala do tuaregue como um aventureiro, como alguém corajoso, que se lança. Eu achei que era uma imagem superinteressante para representar o Saara. O chorinho está presente no filme também, porque remete ao Rio do início do século XX, que é o momento em que aquelas pessoas chegaram ali, que se construiu aquele espaço urbano e arquitetônico. Um senhor que entrevistei também me presenteou com um CD de música árabe cantada por judeus, que utilizei na trilha fílmica. Então você vê como a música também conta essa história, a narrativa daquelas pessoas e ajuda a realçar alguns temas tratados no curta.

Voltando a influência de minha formação em geografia, acho que ela tem tudo a ver com a maneira com a qual a música ganha corpo em meus filmes, porque tem uma ideia que me acompanha sempre em tudo o que eu faço, que é a ideia de paisagem. Porque a gente pensa em paisagem e a entende como algo que está fora, é algo que esta "ali". Mas eu acho muito interessante pensar em paisagem como algo que está "aqui”, dentro de cada um de nós, como sendo algo que é o que você enxerga a partir de um dado absolutamente subjetivo. 
Da mesma maneira há a paisagem de sons, que é o que você escuta quando ouve aquela música, o que nela te mobiliza, então eu acho muito interessante pensar na música dos filmes nessa perspectiva mais internalizada.

G.S.: Você escuta música "romântica"? Qual sua relação pessoal com o gênero?

A.R.: Eu comecei a conhecer esse mundo e me fascinar por ele quando eu morei em Sergipe. Vivi quatro anos lá e no período foi lançado o CD Reginaldo Rossi ao Vivo, que foi um sucesso estrondoso. Eu ouvia aquelas músicas 24 horas por dia, meus vizinhos não paravam de tocá-las, em tudo quanto era lugar se escutava Reginaldo Rossi. Eu sou uma pessoa superligada em música, sou atenta às novidades, gosto de saber o que as pessoas ouvem e essa música nunca tinha chegado aos meus ouvidos. Fiquei louca, apaixonada e cativada desde aquela época. Eu sou carioca e somente ali, no nordeste, tive a oportunidade de conhecer o seu trabalho. Por isso, eu acredito nessa veia nordestina, nessa territorialização da música "brega". No nordeste ouve-se demais e aqui no Rio, nem tanto.

Eu acho que essa escuta é um recorte de classe social também. Houve esse movimento da música brega chegar aos espaços mais elitizados, o que é ótimo... Mas porque para uma música ser considerada legítima precisa passar por esse público intelectualizado e elitizado? Existe um olhar muito depreciativo sobre a cultura de massa, entende? Então se o cantor foi forjado dentro da indústria cultural, como praticamente todos esses artistas nos anos 70 - venderam milhões de discos - são desprezados como algo fabricado, vai ser algo que enfrentará algum tipo de preconceito. Mas o Nelson Ned lotou o Carnegie Hall por dois dias seguidos, uma semana depois do Frank Sinatra, entendeu? São grandes artistas, sabe? O Agnaldo Timóteo tem a Trilogia da Noite, que o Paulo César de Araújo cita no Eu não sou cachorro, não, que é um livro brilhante e fundamental para entender esse universo dos cantores bregas. São discos maravilhosos dos anos 70, com uma orquestração incrível e letras absolutamente contundentes, pessoais, profundas...

A partir do Reginaldo Rossi, eu fiz um filme em 2002 sobre o rio São Francisco, que já tinha algumas músicas da Diana, do Lindomar Castilho. Eu nem sabia quem era Lindomar Castilho nessa época, sabe? Eu fui na casa de uma senhora, que era personagem do filme, e ela estava lá sentada em uma cadeira de balanço ouvindo Lindomar Castilho e eu achei aquilo sensacional. Então foi assim mesmo, nessas andanças pelo interior, que eu comecei a conhecer e gostar dessas canções.

Ao passo que conhecia as canções, eu andava muito no interior por razões de trabalho e conversava com as pessoas. Comecei a perceber, em para- 
lelo a minha entrada nesse mundo musical, que as canções tinham como tema questões muito pessoais, de coisas íntimas, histórias sobre amor, sobre relacionamento, sexo, tratavam estes assuntos de uma maneira muito aberta, muito franca. Aquilo me chamou muita atenção por causa da cultura patriarcal, machista e conservadora. Percebi o quanto as pessoas construíam uma relação liberta com determinados temas espinhosos e fui ligando uma coisa a outra. Ao fato das canções tocarem em assuntos tabus, falarem de um amor aventureiro, de um amor errado, alimentando a ideia que mais tarde daria origem ao filme.

G.S.: Nessa questão da criação do documentário, o que veio primeiro? Você escutava a música e depois ia procurar as personagens?

A.R.: A pesquisa de personagem para o Vou rifar meu coração partiu dessa análise das músicas. De pegar essas músicas, ler, ouvir e entender. De pesquisas também da história desses artistas e da trajetória deles. A partir daí, entendi alguns temas recorrentes, alguns personagens muito importantes, algumas histórias marcantes dessas músicas como, por exemplo, Eu vou tirar você desse lugar. Essa música é um ótimo exemplo de como fiz a pesquisa de personagem para Vou rifar meu coração, porque a história era muito interessante e a gente foi atrás de casais que tivessem se formado dentro do cabaré. É muito mais comum do que a gente imagina, isso pra mim foi revelador, sabe? De confirmar a relação temática das canções com o cotidiano popular.

G.S.: A que se deve essa profusão de filmes documentários e ficcionais sobre o universo musical?

Existe de fato um aumento e uma profusão de documentários sobre música. Eu acho super bem-vindo, adoro ver documentário musical, adoro ver filme sobre música. Você me perguntou como eu identifico esse processo e eu não sei, sabia? Fico me perguntando de onde vem isso, porque fazem tantos documentários musicais, porque isso tá em voga. Talvez porque tenham algumas questões interessantes aí. Primeiro, o entendimento do documentário como um filme que não é necessariamente uma exposição de um acúmulo de informações. Eu acho que a música se presta a falar do mundo num registro da sensibilidade. Então talvez essa coisa dos documentários musicais tenha a ver com isso.

Em relação a esse movimento da produção de documentários musicais, acho que se deveria apostar mais nas músicas que sobrevivem à margem do mainstream, porque a gente vê que a maioria desses documentários aborda os festivais da Record, a Bossa Nova, o universo da MPB, entendendo a MPB como uma música mais elitizada e aceita no meio da crítica musical e presente 
na história oficial. Eu acho que a existência desses filmes reflete a possibilidade de um novo olhar, uma nova perspectiva do que é cultura popular. Porque se a gente observa o Cinema Novo e os documentários que eram feitos naquela época, quando se pensava em representação de cultura popular, pensava-se logo em uma manifestação produzida no meio rural, ligada à tradição, sem influência dos meios de comunicação ou da cultura de massa. Hoje não dá mais pra se pensar dessa forma. A cultura popular não é só Mestre Vitalino, a cultura popular também é o funk carioca, também é a música brega, que é a expressão artística que traduz e carrega uma forma de identificação de um número muito grande de pessoas, de um determinado universo social. 